\author{
ROSA INDELLICATO \\ Aldo Moro University Italy, Bari \\ indellicato.rosa@libero.it \\ ORCID ID: 0000-0001-9585-0726
}

\title{
LINEAR ECONOMY, CIVIL ECONOMY AND CIRCULAR ECONOMY: EDUCATION AS A CATALYST FOR TRANSITION
}

\begin{abstract}
Many people today are raising the issue of sustainable development in the face of the danger of an ecological crisis.

The economic, social and cultural evolution poses questions to which each of us is called to respond by reflecting on what are the emergencies of the planet, but at the same time to operate for the protection of health and the reduction of environmental damage.

The natural disasters that have occurred in recent years lead us to reflect on the responsibility not only of man, but also the social responsibility of governments.

So we ask ourselves: is it possible to achieve a green economy model? A famous economist has already mapped out a path to a non-violent economy, based on a model of accountability.

This model states that every discovery must be evaluated by civil society, taking into account the balance between the resources used and the results obtained.

To achieve a sustainable green economy, it will be essential to build a biodemocracy in which scientific options are widely supported and accepted.
\end{abstract}

KEYWORDS: environmental education, circular economy, responsibility, care 


\section{THE ENVIRONMENTAL ISSUE: THE IMPORTANCE OF EDUCATING FOR ETHICAL RESPONSIBILITY}

In the age of technological rationality, the environmental question must be posed as a question concerning the human being and his education; for this reason it is fundamental to stress the importance of educating to an ethical responsibility for the protection of the environment. This responsibility must be rooted in a dialectic of recognition for the safeguarding of environmental values. We can say that the ethical-educational sensitivity towards the environment has been stimulated, on the one hand, by the explosion of the environmental crisis, due to unlimited development, and, on the other, by an awareness and learning of ecological knowledge, which is allowing us to regain a sense of belonging of man to the system of natural relations. It is only by becoming aware of this meaningful belonging that it is possible to recover ethical behaviour and positive attitudes towards the value of the environment in a world that is changing rapidly. We cannot start from the idea that everything that surrounds us is a reality that is foreign to us and therefore we are in a position to selfishly operate an unlimited exploitation, with the conviction that this reality does not belong to us, while it is true that we are part of that reality and we live in it and with it because we are part of an interrelated 'whole. The extreme, and certainly negative, expressions of the profound ecological crisis that we are experiencing at the beginning of the third millennium are to be found precisely in this sense of extraneousness that has authorised mankind to a senseless manipulation and perverse treatment of nature. Manipulative and despotic attitudes towards nature arise not so much from the idea that it is at man's disposal, but from the conviction that it is something other than us, of which we can do what we like ${ }^{1}$. In contemporary environmental ethics, according to Bartolommei, it is possible to glimpse a position of indifference to the fate of the natural world and another that we can define as sensitive to nature, which in turn is combined in a strong and weak position ${ }^{2}$. On the contrary, it is necessary to become aware of the sense of belonging, to

1 Cfr. su questa tesi S. Bartolommei, Etica e natura: una rivoluzione copernicana in etica?, Laterza, Bari, 1995, in particolare pp.74-83.

2 Cfr. S. Bartolommei, Letica ambientale come nuova frontiera del pensiero morale contemporaneo, in Manuale di etica ambientale, Le Lettere, Firenze, 2009 
respect what is other than oneself, to educate to a responsibility that ethically connotes human behaviour towards the environment. These are the methods that each of us must adopt if we want to contribute to the planetary balance, to a healthy livability on Planet Earth, worthy of a human consortium that wants to call itself civilised, bearing in mind that not committing ourselves in this direction could entail serious risks and threats to human survival itself. The aim is to succeed in defining ourselves as «living beings endowed with a planetary awareness capable of recognising the impact of our choices and our consumption on other peoples, other species and future generations» ${ }^{3}$. Less and less man adapts himself to the world and more and more he adapts the world to himself and, recalling the myth of Prometheus irresistibly unleashed.' And it makes impending dangers, determined by the prevailing adaptation of the world to itself, endanger human life itself. The concept of the "humanisation of nature", writes Jonas, is a hypocritical euphemism for the total subjugation of man in view of an unlimited exploitation that is purely instrumental to the satisfaction of his needs. In order to humanise himself, man has the task of naturalising nature ${ }^{5}$. «Humanised nature is not only that which is subservient to man, but above all that which is free from human intervention and which therefore constitutes the sign of its freedom ${ }^{6}$. Fires, deforestation and climate change are alarm bells of a changing nature and of a man who is increasingly becoming a creator. And it is precisely nature that has not been transformed and exploited by man, "wild" nature, as defined by Jonas, that has the characteristic of being human because it is nature that genuinely speaks to man, while nature that is completely enslaved to man is

\footnotetext{
V. Shiva, Il bene comune della Terra, tr.it., Feltrinelli, Milano, 2011, p. 129.

Cfr. M.L. Furiosi, Uomo e natura nel pensiero di Hans Jonas, Vita e Pensiero, Milano, 2003.

5 Cfr. H. Jonas, Das Prinzip Verantwortung. Versuch einer Ethik für technologische Zivilisation, Insel, Frankfurt a. M. (tr.it. Il principio responsabilità. Un'etica per la civiltà tecnologica, Einaudi, Torino, 1990), pp. 269-270.

6 M. Gennari, Filosofia detla formazione dell'uomo, Bompiani, Milano, 2001, p. 643.
} 
inhuman. ${ }^{7}$ A credible anthropology can only be a personalist anthropology underpinned by a dutiful respect for human dignity and an ethics of responsibility with which man will know how to live in harmony with himself and in interaction with the social and ecological space. Here education will be able to play «an active role in achieving a maturity that calls for autonomy of judgement and action in the face of stereotypical behaviour and thoughts» ${ }^{8}$.

The major changes that are taking place on our planet are causing a great deal of damage to terrestrial and aquatic flora and fauna, not to mention the climate change alarm with greenhouse gases at their highest levels in 800 years, melting glaciers, the extinction of numerous species and rising sea levels. These changes call for an environmental emergency and a tipping point, the "point of no return" beyond which it would be advisable not to go in order to avoid catastrophes that have been announced. There is a great danger that will manifest itself when the issues become more and more dramatic (environmental and economic), which is why action must be taken to prevent environmental disasters that could have disastrous consequences for human survival as well as that of Planet Earth. We must feel a great responsibility for our own lives and for the life of the planet, which means starting right now an education that leads to a cultural conversion and which must above all have the meaning of care and respect for the common home. The form of 'natural' responsibility is similar to the assistance one owes to a person in difficulty. In the same way we should consider nature, the recognition lies in this, that a human value can be transferred to things or in other living beings.

7 Cfr. H. Jonas, Das Prinzip, cit., p. 270. «The monotony of the cereal oceans, for example in Central and Western America, ploughed by solitary harvesters, watered with pesticides by aeroplanes, offers as 'nature' as little hospitality (and moreover with a significantly lower degree of human communicability) as a 'culture' does a large factory [...] from the vegetable example to the animal one, in the incubators and egg factories that today supply supermarkets, in comparison with which the farmer's henhouse with its cock looks almost like a park for the protection of the environment. From the vegetable example to the animal example, in the incubators and egg factories that today's supermarkets provide, in comparison with which the farmer's henhouse with its rooster looks almost like an animal protection park! The extreme degradation of living beings with sentience and the ability to move, transformed into egg and meat machines, deprived of their living environment, imprisoned for their entire lives, subjected to artificial lighting, fed automatically, no longer has anything in common with nature, so it is no longer possible to speak of "welcoming" and "proximity" to man. The same thing applies to prison farms for the production of beef and so on». Ivi, p.271.

M. Gennari, Filosofia, cit., p. 644. 
Thus, value, sensitivity, affectivity, caring and, ultimately, responsibility for objects have a genuinely 'cultural' and anthropological origin. Education, the refinement of taste, increases the promotion of certain realities of the external world to cultural values.

\section{ENVIRONMENTAL EDUCATION BETWEEN CARE AND CIRCULAR ECONOMY}

This is why we necessarily need to be educated in the process of humanisation by carrying out an integrated research itinerary, which considers the educational process in the multifaceted aspects that root it in everyday life, civilisation, Kultur and Bildung. "Education as a catalyst for development is a key point for combating inequality and reducing poverty. Similarly, access to high quality education is a prerequisite for accelerating the achievement of other sustainable development goals. In other words, sustainable development starts with education ${ }^{9}$. The future of society depends on what attitudes towards the world will be formed in children in the earliest years of their lives ${ }^{10}$.

Care understood as taking care of something has a higher meaning because it presents itself as respect and not as protection. Care is that pedagogical category ${ }^{11}$ which is both formation and action. It can be observed that natural responsibility reacts in an immediate way (inter-human relationship), the responsibility that derives from recognition requires cultural mediation ${ }^{12}$. In both situations there is always something that is deemed worthy of being protected, defended, saved, something that arouses care. Man is moved by concern and, as Jonas would say, by the inclination to «fear for the fate of those

9 Qian Tang, Istruzione di qualità, SDG 4, in Verso l'Agenda 2030, https://www.unric. org/.../31354 - obiettivo-4-fornire-uneducazione-di-qualità-equa-ed-inclusiva-e-opportunità-di-apprendimento-per-tutti/.

10 Graca T, Such-Pyrgiel M. Prawa człowieka i ich upowszechnianie w strukturach różnych poziomów edukacji. In Parente F, ed, Prawa człowieka w funkcjonowaniu administracji publicznej. WSGE, Józefów; 2018, 77.

11 Cfr. R. Indellicato, La cura dellambiente come categoria pedagogica, in rivista quadrimestrale "Per la filosofia. Filosofia e insegnamento", anno XXXVII, n. 109-110, maggio-dicembre 2020, Fabrizio Serra Editore, Roma, 2020, pp. 201-209.

12 Cfr. L. Girardello, Lo spirito della dichiarazione universale dei diritti dell'animale: dall'etica alla politica, in Aa.Vv., I diritti degli animali, a cura di S. Castiglione, Il Mulino, Bologna, 1985. 
who are worthy of existing» ${ }^{13}$ because to lose them is also, in some ways, to lose oneself. This is why man is called upon to recover forms of contact with the natural world. This way of relating allows the person to establish communicative links of continuous enrichment and growth. The interdependence that characterises the relationship between man and the environment is the result of a complex interaction with the world, which allows man to attribute to the world the human meaning that must be recognised starting from its concrete reality.

The theme of the relationship between man and the environment has been addressed by various pedagogues who have defined the environment as a living space that influences the individual from a cognitive and psycho-social point of view, and it is easy to understand how important it is to live in a rich and structured environment in order to have a positive impact on the formation of individuals. The issue of sustainability is at the heart of today's debate involving different fields of knowledge (economic, political, educational) and is a global phenomenon because it concerns the entire planet. Ulrich Beck was one of the first sociologists to take an interest in the phenomenon of globalisation, hypothesising the consequences it would have on the planet. In this regard, Beck defines our society as a society of risk and emphasises very strongly that «in the fight against the catastrophe of the planet, new models of global management are being designed and institutionalised and, at the same time, the prestige of the global manager (national technocrat transformed into a global 'ecocrat' with a good conscience) continues to grow» ${ }^{14}$.

In this situation, the model of a civil economy based on fraternity and solidarity can lead to a recovery of the concept of environment, territory and collective well-being. In the civil economy model, trust occupies an important role in fair trade experiences because through trusting relationships the phenomenon of the growth of trust capital is created, which is only possible by investing in interpersonal relationships.

The idea of a society no longer based on utilitarian exchange, but on reciprocity, on gift, on fraternity will be possible when the concept of sustainability will be able to overcome that of economy and profit. Environmental sustainability

13 H. Jonas, Il Principio, cit., p. 118.

14 U. Beck, I rischi della libertà: l'individuo nell'epoca della globalizzazione, Il Mulino, Bologna, 2000, p. 80. 
as the ability to maintain the quality and reproducibility of natural resources, social sustainability as the ability to guarantee conditions of well-being and growth while respecting human rights, economic sustainability as the ability to generate income and work.

The civil economy has led mankind to the conviction that knowing and valuing the environment is an indispensable factor for economic, technological and sustainable growth. «The new environmental culture must, however, stimulate people to make the environment an opportunity in the sense of using green technologies, developing sustainable and safe production cycles, quality and ethical management systems that harmonise with all environmental procedures and marks. The environment, land and production, if well managed, can be the true triad that makes it possible to comply with all the criteria of sustainability and protection of the planet's and man's wellbeing. The compromise between man and the environment, better specified as economy and environment, exists and this is only because man has realised over the centuries that if the environment is depleted or degraded beyond repair, man's safety and survival will also be in danger» ${ }^{15}$.

The challenge for a healthy and sustainable environment also comes from the circular economy which, starting from the famous quote by the French chemist Antoine-Laurent de Lavoisier "Nothing is created, nothing is destroyed, everything is transformed", already two centuries ago seemed to perfectly enunciate the circular economy model based on an economy that turns in the direction of reuse, repair, regenerate, recycle and not the so-called make, take, waste. The green economy is characterised by the green element, which in essence refers to the principle of sustainability with greater integration of environmental and social reality. What is at issue is not economic freedom, but the way in which it is exercised, in the sense of environmental, economic and social compatibility, in the light of the current situation in the world.

The increase in the Earth's population, energy costs, and pollution levels require a circular economy rather than a linear economy to meet basic human needs. The circular economy currently represents a revolutionary model of sustainable development, and we believe that actions are needed to involve

15 A. Romani, Introduzione in Economia, ambiente e sviluppo sostenibile, a cura di Aa.Vv., M. Ciani Scarnicci, A. Marcelli, P. Pinelli, A. Romani, R. Russo, Franco Angeli, Milano, 2014, p. 9. 
and stimulate the various stakeholders. «The circular economy is, in a nutshell, an economy without waste [...] every production process uses inputs (raw materials, food, air, water, soil) and produces residues of various kinds. An "entropic" principle applies to each process: the residues will by definition have degraded compared to the starting inputs, they contain, so to speak, less "potential utility" ${ }^{16}$. Another characteristic element highlighted is the «systemic dimension, i.e. the recognition of the need for a radical rethink of how the economy works in terms of production and business models, consumption patterns, the organisation of work, and the work of public institutions» ${ }^{17}$.

The change of course must take place through a cultural inversion that must start with pedagogy. From this point of view, pedagogy reconsiders the man/ environment relationship in a systemic way, paying attention to anthropological aspects, in order to educate the subject to consider the environment as one of the ontologies of education. Environmental education must become a good practice as also mentioned in the International Conference on Environment and Society: Education and Awareness Raising for Sustainability, held in 1997 in (Greece). All this will be possible by focusing on the training of pupils, increasing a systemic vision of the environment and promoting the formation of an ecological conscience and a relational thought not only with one's own fellows, but with all the living beings on the planet, as reiterated in Agenda 21, which considers it essential to «form an informed conscience in ecology and ethics, in values, in attitudes, for skills necessary for sustainable development and the promotion of effective participation of people in decisions concerning the environment» ${ }^{18}$. What is needed is 'education for the future' with the good intention of encouraging young people to commit themselves responsibly to the creation of a society founded on values linked to development that respects dignity and is based on social justice, as a necessary condition for the survival of humanity. In this sense, pedagogical knowledge can be revolutionary in changing values. Promoting sustainable behaviour in schools makes it possible to reduce the gap between theory and practice, i.e. between all the programmes

16 A. Massarutto, Un mondo senza rifiuti? Viaggio nelleconomia circolare, Il Mulino, Bologna, 2019, p. 11.

17 Ivi, p. 12.

18 Promotion Education, Public Awareness and Training (Promozione dell'Istruzione, della Consapevolezza Pubblica e della Formazione Promozionale), nell'Agenda 21 locale, Conferenza delle Nazioni Unite sull'Ambiente e lo Sviluppo, Rio de Janeiro, 1992. 
ratified in national and international forums and manifested actions. This presupposes a broad-minded and innovative pedagogical mindset in teachers, who are aware of their own life-value choices that translate into teaching (knowledge-action, identity-environment, values and change). Sustainability will be manifested in the action on relationships, structures and spaces, where each actor has an active role and in this way families, associations and the political world, as well as schools, are also subjects who responsibly contribute to the affirmation of lifelong learning experiences in children ${ }^{19}$. This was also reiterated in the 2030 Agenda: «Ensure by 2030 that all learners acquire the knowledge and skills necessary to promote sustainable development, including through education for sustainable development and lifestyles, human rights, gender equality, the promotion of a peaceful and non-violent culture, global citizenship and the appreciation of cultural diversity and the contribution of culture to sustainable development» ${ }^{20}$. The educational system of a school that intends to initiate a process of sustainability must be a school in research, in order to elaborate and build educational and didactic hypotheses to be developed in an interdisciplinary dimension with languages, knowledge, innovative methodological strategies, which can combine the needs of man with the needs of the environment and can establish a dialogue and respectful relationship with the latter. Giving pupils the opportunity to get to know their living environment, the materials and tools used can help to give it a formative value and educate them to a planetary citizenship that can be characterised as responsible citizenship with a view to sustainable development.

Everyday life can be a precious space for continuous learning of good practices and training in ecological thinking, i.e. a way of thinking capable of creating connections and thus forming people who are sensitive to respect for the environment.

19 Cfr. R. Semeraro, L'educazione ambientale come possibile prospettiva dell'educazione permanente, in F. Gobbo, E. Guidolin (a cura di), Formazione permanente e trasformazioni sociali, Cleup, Padova, 1998.

20 https://www.unric.org/it/agenda-2030/30815-obiettivo-4-fornire-uneducazione-di-qualita-equa-edinclusiva-e-opportunita-di-apprendimento-per-tutti. 


\section{REFERENCES}

Bartolommei, S. (1995). Etica e natura: una rivoluzione copernicana in etica? Laterza. Bari.

Bartolommei, S. (2009). Letica ambientale come nuova frontiera del pensiero morale contemporaneo. In: Manuale di etica ambientale. Le Lettere., Firenze.

Beck U. (2000). I rischi della libertà: l'individuo nell'epoca della globalizzazione. Il Mulino. Bologna.

Furiosi, M. L. (2003). Uomo e natura nel pensiero di Hans Jonas. Vita e Pensiero. Milano.

Gennari, M. (2001). Filosofia della formazione dell'uomo. Bompiani, Milano.

Girardello, L. (1985). Lo spirito della dichiarazione universale dei diritti dellanimale: dall'etica alla politica. In: Aa.Vv., I diritti degli animali, a cura di S. Castiglione. Il Mulino. Bologna.

https://www.unric.org/it/agenda-2030/30815-obiettivo-4-fornire-uneducazione-di-qualita-equa-edinclusiva-e-opportunita-di-apprendimento-per-tutti.

Indellicato, R. (2020). La cura dell'ambiente come categoria pedagogica. In: Per la filosofia. Filosofia e insegnamento, anno XXXVII, n. 109-110. Fabrizio Serra Editore. Roma. pp. 201-209.

Jonas, H. (1990). Das Prinzip Verantwortung. Versuch einer Ethik für technologische Zivilisation. Insel,.Frankfurt a. M. (tr.it. Il principio responsabilità. Un'etica per la civiltà tecnologica, Einaudi, Torino).

Massarutto, A. (2019). Un mondo senza rifiuti? Viaggio nelleconomia circolare. Il Mulino. Bologna.

Promotion Education. (1992). Public Awareness and Training (Promozione dell'Istruzione, della Consapevolezza Pubblica e della Formazione Promozionale) nell'Agenda 21 locale Conferenza delle Nazioni Unite sull'Ambiente e lo Sviluppo. Rio de Janeiro. Romani, A. (2014). Introduzione in Economia, ambiente e sviluppo sostenibile. A cura di Aa.Vv., M. Ciani Scarnicci, A. Marcelli, P. Pinelli, A. Romani, R. Russo, Franco Angeli. Milano.

Semeraro, R. (1998). L'educazione ambientale come possibile prospettiva delleducazione permanente. In: F. Gobbo F. Guidolin E. (a cura di), Formazione permanente e trasformazioni sociali, Cleup. Padova.

Shiva, V. (2011). Il bene comune della Terra. Tr.it. Feltrinelli. Milano.

Tang Qian. Istruzione di qualità. SDG 4. In: Verso l'Agenda 2030. https://www.unric.org/.../31354 - obiettivo-4-fornire-uneducazione-di-qualità-equa-ed-inclusiva-e-opportunità-di-apprendimento-per-tutti 